European Journal of Pragmatism and American Philosophy

$\mid-1 / 2$ | 2009

Europe and American Pragmatism: Influences and Interactions

\title{
Why American Philosophy? Why Now?
}

Larry A. Hickman

\section{(2) OpenEdition \\ Journals}

Electronic version

URL: http://journals.openedition.org/ejpap/964

DOI: 10.4000/ejpap.964

ISSN: 2036-4091

Publisher

Associazione Pragma

\section{Electronic reference}

Larry A. Hickman, «Why American Philosophy? Why Now? », European Journal of Pragmatism and American Philosophy [Online], I-1/2 | 2009, Online since 01 July 2009, connection on 08 May 2019. URL : http://journals.openedition.org/ejpap/964; DOI : 10.4000/ejpap.964

This text was automatically generated on 8 May 2019.

\section{(c)}

Author retains copyright and grants the European Journal of Pragmatism and American Philosophy right of first publication with the work simultaneously licensed under a Creative Commons AttributionNonCommercial-NoDerivatives 4.0 International License. 


\title{
Why American Philosophy? Why Now?
}

\author{
Larry A. Hickman
}

1 This title presents not two, but three questions. The third question, the one that lies behind and is obscured by the two more obvious ones, concerns the nature of American philosophy. What qualifies as "American" philosophy? Is it, as some have suggested, philosophy as it is practiced in any of the Americas - North, Central, or South? Or is it perhaps philosophy as it is pursued by practitioners living in North America, or even in a more restricted sense, by practitioners living in the United States of America?

2 My own suggestion is that there is a strand of philosophy that is typically American and that is different from, but related to, philosophy in Latin America. It is also different from, but related to, philosophical imports, such as Anglo-American analytical philosophy and so-called "continental" philosophy as they are practiced in the United States of America.

3 I harbor no illusion that my suggestion has been, or will be, widely accepted. Several years ago, for example, I received a copy of a book whose title was "American Philosophy of Technology." I turned to the table of contents with some excitement, expecting essays on John Dewey's critique of technology, or even the instrumentalism of William James. But that was not to be. It contained instead essays written by six highly regarded Dutch philosophers about six highly regarded philosophers of technology who live and work in the United States. Five of the six essays focused on philosophers working in the following traditions: 1) Heidegger, 2) Heidegger, 3) Marcuse, 4) Heidegger and Merleau-Ponty, and 5) Critical Theory. The sixth involved a feminist approach to technology. No Dewey. No James. (I should add that I found the book very informative, and I applaud the work both of the essayists and their subjects. But I must also admit that I remain puzzled by the title. Should it not have been "Philosophy of Technology in America"? I have a very different sense than do the editors of this book of the traditions that I identify with "American philosophy.") 
The American philosophy that I know is deeply rooted in the history of its native country. That is not to say that it somehow began from scratch, that nothing has been imported from abroad. When the Puritans came to New England in the 17th Century, for example, they brought with them ideas and practices that had been influenced by their time in England and the Netherlands. But they were very soon faced with new conditions which demanded that old tools, the conceptual ones as well as the tangible ones that fit their hands, be modified for the new environment and the new tasks they faced.

5 And even though Jonathan Edwards did much of his influential work on the frontier, we can now see that he was in dialogue with the main trends of contemporary philosophy as it was practiced in England and elsewhere. But we also know that his work was designed to respond to the new challenges that presented themselves as the narrow vision of Puritan Calvinism began to dissolve in response to the vastness of the geographical and intellectual possibilities of the new landscape. This was a uniquely American task.

Despite his own claims to the contrary, even Charles Peirce - who was probably one of the best-read philosophers of his generation when it came to the history of European philosophy - even Charles Peirce exhibited this American preoccupation with tools and instruments. In his hands, and in the hands of his successors, William James and John Dewey, concepts were treated not as complete in themselves, but as tools for further inquiry. Even a cursory review of Pierce's treatment of habits bears this out.

7 As for John Dewey, on the occasion of his 90th birthday the New York Times hailed him as "America's Philosopher." It would take a sizeable essay in itself to discuss the many ways that Dewey's philosophical work departed from the traditions of philosophy as it was practiced in Europe. Put in contemporary terms, however, I believe that Dewey's position amounted to a kind of "post-postmodernism." Along with (or one should perhaps say "in anticipation of") contemporary French-inspired postmodernists (and their cousins, the Rorty-inspired neo-pragmatists), Dewey rejected the long tradition of static, substanceaccident metaphysics. The bare-bones metaphysics that Dewey retained consists only of what he termed "generic traits of existence," adding that such traits are more general than science and more specific than common sense. And of course Dewey's work shares the postmodernist disdain for foundationalism as well.

Beyond that, however, here is the point at which, in my view, Dewey's philosophical work is both distinctively American and richly relevant to the resolution of difficulties encountered in the philosophical traditions that have flourished in Europe. Because of his rich treatment of concepts and hypotheses as instrumental, his insistence that there is a commonality of human life and that our understanding of it is grounded in the biological and anthropological sciences, and his commitment to a hard-headed notion of referentiality, Dewey's American, broadly-experimentalist philosophy avoids some of the central problems of both the Anglo-American analytic tradition and French-inspired postmodernism (and its neo-pragmatist American cousins).

Why is this approach to philosophy distinctively American? The answer to this question lies in its treatment of concepts as instruments that are malleable, but not infinitely so (as the postmodernist preoccupation with the infinite variations on the literary trope and the Rortian commitment to infinite re-descriptions would have it); and in its commitment to the hands-on, rough-and-tumble engagement with stubborn facts, especially those having to do with social problems, in ways that treat analysis as but one phase of concrete problem solving and not as an enterprise sufficient unto itself (as some of the more 
etherial exercises of conceptual analysis would have it); and in its insistence on a philosophy that is democratic in its methods and outlook because it is committed to a pedagogy that lies at the heart of democratic life and the continual reform of democratic institutions.

Put another way, one of the central strands of American philosophy, Pragmatism, offers a third option, between Anglo-American conceptual analysis and French-inspired postmodernism. Its broad reach transcends the analysis of concepts and definitions in order to engage the real-world problems of men and women. And at the same time it rejects the notion of a "grand narrative," it also transcends the postmodernist denial of commonality and referentiality. It engages the physical and social sciences, as well as technology, in ways that are rarely found within other philosophical traditions. (Contrary to the claims of some of his critics, Dewey also rejected the positivists' search for the "foundations" of science and mathematics, which he thought worked quite well enough and thus required no foundations.)

Why American philosophy? Why now? My suggestion is that during this time in which the means of communication are ubiquitous, when previously isolated cultures are rubbing up against one another as never before, and when it is essential that we find commonalities that we can use as platforms for constructing a better world, American Pragmatism is made-to-order for the task. If you want to reject foundations; if you want to jettison the baggage of static metaphysics; if you want to treat the results of inquiry as both warranted and assertible (although potentially fallible); if you want to engage concrete social problems; if you are ready to articulate and deploy a thick pedagogy that balances the needs of student and curriculum; if you look to the sciences, the humanities, and the arts as informing and informed by philosophical inquiry and thus as sources of philosophical insight and renewal - then you are aligned with the program of American Pragmatism.

12 American philosophy has its roots in the experimentalism that was required by a people who faced the task of coming to terms with the uncertainties of a radically new environment. But a true experimentalism always reaches out in an attempt to be inclusive - as American Pragmatist Jane Addams learned to do during her late 19th and early 20th century experiments with Hull House, the settlement house located in a section of Chicago where recently arrived immigrants spoke more than a score of different languages and where sharply differing customs rubbed up against one another. Her search for unity in diversity - a richly American concept - was to become a central feature of Dewey's philosophical outlook.

13 Why American philosophy? Why now? Because the world is smaller and more crowded today than it was yesterday, and we need to employ experimentally based and philosophically informed methods if we are to meet the challenges of our developing milieu, and to flourish in the process. 